УДК 159.9.018.4

\title{
СМЫСЛОВОЕ РАЗВИТИЕ УЧАЩИХСЯ СРЕДСТВАМИ МЕЖПРЕДМЕТНОЙ ИНТЕГРАЦИИ
}

\author{
Дышлюк Ирина Станиславовна
}

Согласно смыслодидактике обучение предстает как смыслообразующий, смыслосозидающий процесс, как механизм, который запускает и обеспечивает смысловое развитие учащихся. При таком подходе содержание учебного прочесса предстает в качестве основы, способствующей смысловому развитию школьников [1, с. 7]. Межпредметная интеграция дает больше возможностей для создания единого смыслового пространства и развития способности учащихся к смыслообразованию.

Ключевые слова: межпредметная интеграция, факторы интеграции, смыслообразование, смысловое пространство.

\section{LEARNERS' SENSE DEVELOPMENT BY MEANS OF INTERSUBJECT INTEGRATION}

\section{Dyshliuk Irina Stanislavovna}

According to sense-didactics training is a sense-creative, sense-generative process, a mechanism of launching and providing learners' sense development. This approach considers the content of the educational process as a foundation promoting schoolchildren's sense development. Intersubject integration provides more opportunities for creating a single sense space and developing pupils' ability to sense-creation.

Keywords: intersubject integration, integration factors, sense-creation, sense space.

Глобальной целью, стоящей перед учебным процессом, является становление целостной личности школьников. Предметное построение учебного процесса и потребности учащихся в целостных представлениях о мире рождают противоречия, которые способна сгладить, хотя бы отчасти, межпредметная интеграция, прежде всего в сфере содержания образовательного процесса.

Актуальность идей межпредметной интеграции состоит в следующем:

- современное узкопредметное содержание образовательного процесса не способствует осуществлению глобальной цели образования - обеспечению 
целостного развития личности, решить данную проблему в состоянии межпредметное интегрированное обучение;

- механизм интеграции (способность к синтезу информации) заключен в самой природе человеческого мышления, диктуется объективными законами психологии и физиологии;

- интегрированное содержание (слияние разнохарактерных знаний, способов деятельности, интеллектуальных технологий) содержит в себе больше возможностей для развития интеллектуальных, творческих способностей учащихся;

- межпредметная интеграция способствует интенсификации предметного содержания.

Интеграцию можно трактовать как ведущую форму организации содержания образования на основе всеобщности и единства законов природы, целостности восприятия субъектом окружающего мира. Суть интеграции - в поиске единого объединяющего начала, присущего разнохарактерному содержанию и, как следствие, в создании нового интегрированного содержания.

Межпредметное интегрированное содержание способствует формированию системности знаний, творческих способов познавательной деятельности и личностно-смысловых ориентаций учащихся. Такая система организации учебного процесса способствует формированию у обучающихся целостных представлений о мире, формированию ориентировочной основы действий в пределах всего содержания образовательного процесса, оптимизирует личностно-смысловую сферу школьников [3, с. 12]. Межпредметная интеграция способна придать личностный смысл одним областям знаний за счет удовлетворения интересов учащихся в других областях знаний. К примеру, специальный интегративный курс «История и математика», читаемый в математическом классе, может повысить интерес к истории и придать личностный смысл историческим знаниям за счет того, что математические задачи будут строиться на историческом материале.

Межпредметная интеграция формирует целостно-значимую картину мира для учащихся, т. к. полипредметная основа или среда, которую она создает, дает больше возможностей для создания единого смыслового пространства и развития способности учащихся к смыслообразованию, т. е. к постижению, пониманию изучаемого. В данном случае содержание учебного процесса выступает как субстанция, питающая смысловое развитие личности, а методы, технологии - как механизмы, запускающие смысловое развитие, что, в свою очередь, ведет к целостности личности $[1$, c. 7]. Таким образом, межпредметная интеграция может осуществляться 
как на уровне содержания (знаний, способов деятельности, интеллектуальных технологий), так и на уровне механизмов ее реализации - образовательных технологий.

Обосновывая актуальность и необходимость межпредметной интеграции, следует учитывать познавательные возможности учащихся. Общеизвестно, что для овладения усложненными знаниями нужна соответствующая психологическая основа (наблюдательность, память, внимание, мышление, речь и т. д.). Особенно необходимо хорошо развитое понятийное мышление, поскольку оно обеспечивает формирование у учащихся понятий межпредметного характера. Эти понятия значительно глубже и шире по сравнению с понятиями, относящимися к какой-либо одной из наук, т. к. знания, наполненные личностным смыслом, позволяют преодолеть барьер между изучаемым и постигнутым. Можно говорить о том, что межпредметное интегрированное содержание не просто расширяет смысловое пространство для учащихся за счет разнопредметного содержания, а способствует возникновению в сознании учащихся смыслов высокого порядка, смыслов бытия, например гармонии мира.

Рассматривая межпредметную интеграцию, особо нужно выделить вопрос о ее факторах, т. е. таких компонентах содержания, которые способны соединять разнохарактерное содержание, включаться в содержание иного характера и притягивать к себе содержание другого рода.

К межпредметным факторам интеграции можно отнести следующие:

Проблемно-предметное содержание (проблема данного предмета в других предметах).

Речь идет о том, что, хотя предмет и ограничен строгими рамками, его проблемы, зачастую, «всплывают» и в содержании другого предмета. Стержень межпредметных проблем составляют ведущие идеи, общие для интегрируемых курсов. Процесс решения межпредметных учебных проблем предполагает ознакомление учащихся с общенаучными методами познания, с такими методологическими понятиями, как проблема, гипотеза, метод и т. д.

Выдвижение учебной проблемы требует обобщения разнопредметных знаний. Это могут быть методологические, нравственно-эстетические, научные проблемы современности, которые имеют комплексный характер. Такая комплексность неизбежно «затронет» внутренние установки детей: и мировоззренческие, и нравственные, и духовные, - а это значит, что учебный процесс будет способствовать смыслообразованию учащихся.

Математика и история имеют разнохарактерное содержание и, тем не менее, проблемы истории возникают в курсе математики, когда речь идет о развитии математического знания, жизни ученых. А математика начинает «работать» в истории, когда речь идет о хронологии, счете лет в истории. 
Например, проблема женщины в русской литературе, философии (как литературная, философская проблема); или роль личности в истории, литературе, философии, психологии (как историческая, литературная, философская, психологическая проблема).

Конкретный факт (событие).

Речь идет о событиях, фактах, которые повлияли на все содержание образовательного процесса. Каждый предмет обладает своим конкретным «набором», своей системой изучения фактов. Вместе с тем, многие из этих фактов находятся в определенных отношениях к фактам другим - родственным им, иногда даже сравнительно «далеких» друг от друга предметов. Действительно, в той или иной группе предметов есть существенные факты, общие или близкие друг к другу. Есть факты, касающиеся всего содержания образовательного процесса. Это могут быть войны, природные катаклизмы глобального масштаба. Так, факты географического прошлого России поразному отражаются в истории, обществознании, литературе, музыке, ИЗО, в содержании таких учебных предметов, как русский и иностранный языки [2, с. 4].

На межцикловом уровне (взаимосвязь гуманитарных и естественнонаучных дисциплин) связи между фактами не носят столь широкого характера, но все же их следует постоянно учитывать. Так, учителя естественнонаучных дисциплин обращаются к фактам общественной жизни, когда освещают те или иные моменты из истории науки или раскрывают экологические проблемы. «Мы должны стараться понять, каким образом общество влияет на точные науки и это часто значительно углубляет наше понимание направлений, господствующих в этих науках», - пишет Д. Я. Стройк в работе, посвященной истории математики [4, с. 208].

По-своему оцениваются научные открытия, достижения производства в гуманитарных предметах. Литература и искусство раскрывают гуманистическую сущность фактов науки и техники опосредованно. Не каждый из изучаемых фактов служит базой теоретических обобщений; есть факты, например, в истории, имеющие самостоятельную ценность. Осмысление и обобщение фактов является закономерностью науки. Познавая многие факты, учащиеся поднимаются к обобщениям - философским, экономическим и др., к пониманию идей, теорий, законов, к овладению определенными понятиями [2, с. 5]. Добавим, что т. о. они поднимаются к смысловым обобщениям, что способствует формированию в сознании целостной картины мира.

Базовое, крупное понятие.

Превращение понятий частных наук в общенаучные является закономерностью науки. В образовательном процессе, его содержании межпредметные понятия способны играть роль интегрирующего фактора. 
Можно назвать ряд понятий, особенно крупных, находящих свое отражение в различных предметах. Это так называемые общенаучные понятия. К таким понятиям можно отнести: «время», «пространство», «движение», «ряд», «функция», «система координат» и т. д. В курсе литературы мы говорим о художественном времени, в курсе биологии - о биологическом времени, в курсе истории - об историческом. В курсе математики речь может идти о математическом ряде, на уроках по музыке - о музыкальном. То же касается изучения «системы координат» в курсе математики и в курсе географии, исторического, географического, астрономического пространства; исторического географического, физического движения.

идеи, теории учебного курса.

В содержании образовательного процесса есть идеи и теории, познаваемые в процессе изучения как всех школьных предметов, так и в процессе изучения предметов определенных циклов (гуманитарного и естественнонаучного). Изучая гуманитарные предметы в разных ракурсах и разном объеме, учащиеся познают теории происхождения государства, осваивают идеи цивилизационного подхода к истории человечества, специфику логического и художественного мышления, теорию народонаселения, интеграционные процессы и т. д.

В процессе изучения естественнонаучных предметов учащиеся знакомятся с теорией строения вещества, теорией относительности, квантовой теорией, экологическими проблемами, идеями единства живой и неживой природы, взаимодействия элементов физических, химических и биологических систем и др. [2, с. 8]. Наконец, есть идеи и теории, познаваемые в процессе изучения всех школьных предметов (всеобщая связь явлений, единство единичного, особенного и общего отношения «природа - общество - человек» и т. д.).

Персонализация содержания (эпохализация).

Разнопредметное содержание может быть интегрировано на уровне личности. Личность может знаменовать собой целую эпоху и влиять на развитие науки и, как следствие, на содержание образования. Наглядным примером может служить эпоха И. В. Сталина, личность И. В. Сталина, эпоха Петра I, личность Петра І. В соответствии с данным подходом, можно создать интегрированный курс «Великие имена России», где рассматривались бы известные персоналии и их вклад в развитие России. Безусловно, здесь будут присутствовать имена М. В. Ломоносова, П. Я. Чаадаева, А. С. Пушкина, И. П. Павлова и др.

Таким образом, проблемно-предметное содержание, конкретный факт, крупное понятие, идеи, теории учебного курса, персонализация содержания могут являться факторами межпредметной интеграции, которая создает все 
предпосылки для создания смыслового пространства, являющегося основой для смыслообразования школьников.

Интеграция может осуществляться не только на уровне знаний, но и на уровне способов деятельности и интеллектуальных технологий.

Наряду с овладением знаниями, в процессе обучения у учащихся происходит формирование определенных способов деятельности. Некоторые способы деятельности носят сугубо предметный характер (локализация событий во времени в курсе истории, проведение лабораторных работ в курсах физики или химии и т. д.). Другие характерны для разных групп предметов и предметных областей (работа с картой, схемой, статистическим материалом в предметах, изучающих основы общественных наук; грамматический разбор в предметах лингвистической группы; эстетический анализ произведений искусства в предметах искусствоведческой группы).

Существуют и межпредметные способы деятельности. К последним относятся: рациональный учебный труд (работа над книгой - выбор и общая оценка книги, выделение главных мыслей абзаца, главы, книги в целом, пользование дополнительной, справочной литературой, картинкой и т. д.), речевое воспроизведение и анализ готового текста, составление текста собственного высказывания, умение работать с диаграммами, схемами, статистическими данными и т. д. [2, с. 11]. Названные способы деятельности могут стать основой межпредметной интеграции и, кроме того, способствовать формированию метапредметных результатов обучения, которые в качестве основных провозглашаются новыми ФГОС.

Началом межпредметной интеграции в единую содержательную систему могут стать интеллектуальные технологии. К ним относятся элементы формальной логики (понятия, суждения, умозаключения, анализ и т. д.). Это т. н. «инструментарий» учебного труда [2, с. 19]. Интеграция на уровне интеллектуальных технологий способна синтезировать самое различное содержание.

Историю, литературу, биологию, химию могут интегрировать такие интеллектуальные технологии, как описание явлений и их оценка. У математики и истории точки соприкосновения - развитие логического мышления (умение логически обосновывать суждение, проводить систематизацию). Математика может много дать истории в этом плане.

Межпредметный характер интеллектуальных технологий очевиден. Овладение интеллектуальными технологиями обеспечит большую глубину и системность «предметных знаний», развитие интеллектуальных способностей учащихся, их личностно-смысловое развитие.

Образовательные технологии, как и содержание, могут выступать в роли факторов межпредметной интеграции. Это могут быть, в частности, 
межпредметные познавательные задачи. Межпредметные задачи находятся на стыке разнохарактерных систем знаний и способов деятельности. Решение таких задач позволяет учащимся подняться на уровень межпредметного обобщения, формирует у них целостное понимание и ориентировочную основу действий высокого уровня обобщения. В качестве факторов межпредметной интеграции технологического плана могут также рассматриваться межпредметные задания и дидактические игры, мысленное путешествие, диалог, модульное обучение, уроки интегративного типа, а также новые организационные технологии: учебный день, учебная неделя.

Способность к смыслообразованию предполагает погружение и ориентацию учащихся в широком смысловом контексте, умение видеть и понимать существенные связи и взаимодействия, обобщение представлений учащихся на мировоззренческом и метапредметном уровнях. Данное обстоятельство особенно важно в условиях реализации ФГОС нового поколения, которые, определяя результаты образования, на первое место выдвигают личностные результаты, затем метапредметные, потом уже предметные. Все это может обеспечить применение межпредметной интеграции в учебном процессе.

Таким образом, курс на межпредметную интеграцию в учебном процессе неизбежно приведет к тому, что из сферы межпредметной интеграции мы попадем в сферу культуры вообще, где будут размыты рамки между естественнонаучной и гуманитарной культурой, а приоритетными станут духовные ценности и представления о человеке как главной ценности.

\section{Литература}

1. Абакумова И. В. Смыслодидактика. Учебник для магистров педагогики и психологии. - М.: КРЕДО, 2008. - 386 с.

2. Беленький Г.И. О сущности и видах межпредметных связей // Некоторые теоретические и практические аспекты межпредметных связей. - М.: АПК СССР, 1982.

3. Дышлюк И. С. Содержание образовательного процесса как фактор межпредметной интеграции. Курс лекций. - Ростов н/Д: Изд-во ЮФУ, 2008. - 96 c.

4. Стройк Д. Я. Краткий очерк истории математики. - 3-е изд. - М.: Наука, 1964.

\section{References}

1. Abakumova I. V. Smyslodidaktika. Uchebnik dlia magistrantov psikhologii i pedagogiki [Sense didactics. Textbook for master students in psychology and pedagogics]. Moscow, KREDO Publ., 2008. 386 p. 
2. Belen'kii G. I. O sushchnosti i vidakh mezhpredmetnykh sviazei. Nekotorye teoreticheskie i prakticheskie aspekty mezhpredmetnykh sviazei [On the essence and types of intersubject communications. Some theoretical and practical aspects of intersubject communications]. Moscow, USSR AgroIndustrial Complex Publ., 1982.

3. DyshliukI.S.Soderzhanieobrazovatel'nogo protsessa kakfaktormezhpredmetnoi integratsii. Kurs lektsii [The content of the educational process as a factor of intersubject integration. A course of lectures]. Rostov-on-Don, Southern Federal University Publ., 2008. 96 p.

4. Stroik D. la. Kratkii ocherk istorii matematiki [A brief sketch of the history of mathematics]. Moscow, Nauka Publ., 1964. 